\title{
The Sultan and the Soup: A Javanese Cultural Response to COVID-19
}

\author{
Maila D.H. Rahiem ${ }^{1}$ \\ Faculty of Education, UIN Syarif Hidayatullah Jakarta, Indonesia \\ Husni Rahim \\ School of Graduate Studies, UIN Syarif Hidayatullah Jakarta, Indonesia
}

\begin{abstract}
During the initial outbreak of COVID-19 in Indonesia, a poster claimed to be a suggestion from the Sultan of Yogyakarta Hamengkubuwono $\mathrm{X}$ ( $\mathrm{HB} \mathrm{X})$, who is also the governor of the Yogyakarta Special Area (DIY), to cook and eat sayur lodeh (soup) together to help repel the plague, was circulated through WhatsApp (WA) and Social Media. The Office of Public Relations and Protocol of DIY later refuted this message. This study investigated what sayur lodeh is, what messages were contained in the poster, and how the Javanese perceived these messages within the COVID-19 context. This study used qualitative content analysis as the research method. The researchers made inferences on the meaning inside the message from HB X using cultural perspectives. The data reveals 1) Sayur lodeh is a traditional Javanese dish that includes various nutritious vegetables that are stewed in coconut milk; 2) the order to cook sayur lodeh indicates the Javanese people's high trust in the Sultan in difficult times, the hopeful and constructive attitude to the adversities, the family support, and community's unity to resolve difficulties, and God's belief in moving forward; 3) the Javanese cooked sayur lodeh immediately, as most of them believe that it might help them escape misfortune; this assurance has been passed down from generation to generation. This study demonstrates how culture plays an important role in cultural communities, such as the Javanese, who respect and listen to cultural leaders more than other authorities. People could also obey orders against rationale or the rule of government as they have powerful cultural convictions. This study encourages the participation of cultural figures in emergency or health crisis measures, and any interventions should consider the cultural context of the population.

Keywords: coronavirus, culture, herbal medicine, indigenous, Javanese, Indonesia.
\end{abstract}

The first cases of COVID-19 in Indonesia were confirmed on March 2, 2020 (Burhan et al., 2020; Tosepu et al., 2020). The number of cases quickly increased, and COVID-19 was declared a global pandemic on March 12, 2020 (Platto et al., 2020; Spinelli \& Pellino, 2020). Measures taken over the subsequent weeks dramatically altered people's everyday lives (Platto et al., 2020; Remuzzi \& Remuzzi, 2020). The world has undergone major changes and has transformed typical social practices (Dein et al., 2020; Garbe et al., 2020). Visiting parents, family, or friends has

${ }^{1}$ Corresponding Author E-Mail: mailadinia@uinjkt.ac.id 
become subject to various restrictions, if not impossible. Social distancing, no more handshaking, no more hugs, no more dinners, parties, holidays, or even condolences to those who lost their loved ones due to COVID-19 have become part of daily lives. School and office closures, lockdowns, and travel limitations have all impacted upon people's mobility. Nothing is normal any longer (Buduneli, 2020; Tarman, 2020).

A pandemic generates its empirical reality as a backdrop for all types of psychiatric disorders (Cohen et al., 2007; Goldberg, 2020; Hisham et al., 2020; Holmes et al., 2020; Lazzari et al., 2020; Shigemura et al., 2020; Spoorthy et al., 2020; Vetter et al., 2016). Depression and other mental health problems are validated by economic crises, work layoffs, extended school, company closings, and threatened supply chain disturbances (Goldberg, 2020). COVID-19 has brought the world to a halt as most nations have endured lockdowns that enshrine fear and uncertainty and provoke the population's distinct cultural and psychological conditions (McCorkle, 2020; Ncube \& Motalenyane, 2020; Sikhangezile \& Modise, 2020). Society was hit with fear and chaos; COVID-19 is threatening health problems on a scale that has never even seen before by the present generation, with the "Spanish flu in 1918," perhaps being the last outbreak to have had such severe consequences (Hisham et al., 2020).

Moreover, the stream of news about the outbreak has led to increasing public worry and frustration. Some information is untrue, and certain directions seem contradictory (Mian \& Khan, 2020). Such confusion is not all malevolent, although its effects may be debilitating (Garrett, 2020). In Indonesia, constant coverage of COVID-19 reported cases and deaths and specifics of how deadly the virus is prevalent in the nation's 567 conventional media and 2,011 online media outlets and has generated a terrifying specter that might be deceptive and mislead the population and result in psychological distress, deprivation, panic, and even anxiety that affects Indonesians' physical and psychological well-being (Abdullah, 2020). Many people have relied on culture, religion, and tradition during the unprecedented time of COVID-19 (Dein et al., 2020; Hamzah, 2020; Li \& Lau, 2020), particularly those whose cultures are tightly intertwined and often reinforced by daily rituals (Tagat \& Kapoor, 2020).

Some indigenous communities in the United States have tried alternative methods to combat this pandemic by using traditional wisdom and adopting aspects of their spiritual wellbeing (Airhihenbuwa et al., 2020). In China, people have used traditional Chinese medicine to prevent and control measures of COVID-19 utilizing 28 traditional medicine guidelines to provide treatment measures for COVID-19 (Ang et al., 2020). Traditional Chinese medicine has its features a holistic concept, the balance of Yin and Yang, syndrome differentiation and treatment, strengthening the body's resistance to eliminate pathogenic factors; moreover, traditional Chinese medicine has thousands of years of experience in regulating the body and enhancing the resistance to epidemic diseases, with unique insights and prevention and control experience (Ren et al., 2020).

Tagat and Kapoor (2020) addressed how people in India responded to the fight against COVID-19 in a unique cultural way, ranging from chants of, "Go, Corona go!" (aimed at moving it away, not as a cheer) to non-scientific suggestions about drinking urine from cows. As in India, public belief in their cultural roots also exists in Indonesian society, where culture and values are saturated throughout everyday life.

There are 633 recognized ethnic groups in Indonesia (Central Bureau of Statistics of Republic of Indonesia, 2015). The largest ethnic group is the Javanese, which makes up about 40\% of the total population, with approximately 100 million inhabitants (Ananta et al., 2015). The Javanese (Indonesian: Suku Jawa or Orang Jawa) are an indigenous ethnic group on Indonesia's Java island. With approximately 100 million population, it is the largest ethnic group in Indonesia (Ananta et al., 2015). The Javanese are concentrated on the island of Java, but millions have moved to other islands across the vast archipelago. 
The Javanese have responded culturally to COVID-19, including cooking certain foods to repel the pandemic. In the third week of March, instructions to cook sayur lodeh to ward off COVID-19 circulated widely through WhatsApp (WA) groups, especially among Javanese communities in Central Java and Yogyakarta. The message stated that Sultan HB X, the Sultan of Yogyakarta, who is also the governor of the Special Region of Yogyakarta (DIY), recommended making sayur lodeh, a popular Javanese-origin vegetable soup or curry, and eating together with others to prevent the plague. So, consequently, people began cooking sayur lodeh in the hope of avoiding this deadly disease.

The portrait of Sultan HB sitting confidently and with dignity can be seen in the circulating poster. The messages in the poster are written in the Javanese language, which seems to be an appeal from the Sultan, asking people to cook sayur lodeh and eat it together to prevent becoming infected with COVID-19, while the poster also contained information about the seven ingredients that should be found in sayur lodeh. This message was later denied by the DIY public relations and protocol secretariat, which stated that the WA messages were hoaxes (Rustan, 2020).

This hoax order was immediately circulated shortly after confirmation of the second case of COVID-19 in Yogyakarta. The second confirmed case in the province was a University Gadjah Mada (UGM) professor, and the first confirmed case was a 3-year-old (Muryanto, 2020). Governor HB X of Yogyakarta urged residents to undertake preventive measures to curb the spread of COVID-19 in the province, including washing their hands regularly with soap and water. This was clearly in response to the earlier message that had been widely circulated in the community about cooking sayur lodeh, which remains a mystery concerning who wrote and then distributed the hoax message.

The people of Yogyakarta and its surrounding areas and the Javanese, in general, are considered to have great confidence and admiration for their Sultan. Therefore, they followed the instructions and immediately cooked and ate sayur lodeh together, even if it contradicted the government's order to avoid gathering with other people and remain at home. The order was alleged to have been a fraudulent message from the Sultan. However, in the past, this suggestion to cook sayur lodeh to prevent a plague was also circulated. In 1931, during the reign of Sultan Hamengkubuwono VIII, Java endured a wave of the bubonic plague for more than two decades; it was reported that Sultan Hamengkubuwono IX also recommended sayur lodeh in response to the health crises of 1946, 1948, and 1951 (Rasyid, 2020). Javanese food, in its entirety, is rich in symbolism (Elmira, 2020). The sayur lodeh ritual is an example of slametan, a form of communal ritual. A communal ritual is the main feature of Javanese culture (Geertz, 1964; Lestari et al., 2019; Ricklefs, 2006; van den Boogert, 2017).

The term slametan originates from the Javanese slamet, and most likely also from Arabic salam which means peace. It implies well-being, harmony, protection, fitness, and goodness and wholeness. Slamet means that you are protected, in the way that things may escape issues or challenges arising from natural or supernatural circumstances (Hakam, 2017). Slametan is an important rite for Javanese Muslims, referring to a large communal prayer, feast, and food-offering to mark or honor vital life cycles, including birth, marriage, and death (Nasir, 2019). Muqoddam and Maghfiroh (2019) explored the modes, method, and syncretism patterns of the slametan tradition. Their study found (1) Slametan forms commonly entail birth, death, marriage, village cleaning, feast day, welcoming Ramadhan, cheering work after returning from overseas, and praising when harvest falls. (2) The method of slametan consists of serving food and prayer. (3) As a cornerstone of 'Islam Nusantara' or Indonesian Islam, a slametan culture is a form of syncretism among Java and Islam. 
Culture is about permanent beliefs, and individuals develop such beliefs either in their own native culture or in the cultures with which they are associated (Daghfous et al., 1999; Strunc, 2019). These beliefs affect the way people see the world (Malai \& Speece, 2005). Shavvit \& Barners (2018) argue that culture comprises common traits that provide norms among those who share a language, a historical time, and a geographical location to interpret, believe, assess, interact, and act. Culture acts as a source of world theories and influences how people participate, think, and react, forming their views and philosophies of existence (Kastanakis \& Voyer, 2014). Kastanakis and Boyer (2014) provided a structured review of the role of culture in shaping individual perception, and concluded culture affects perception and subsequently cognition at both the society and individual level and perception and cognition play a central role in subjective human experience. Zou et al. (2009) convinced that culture influences people who perceive that conventional beliefs are culturally consensual.

This research examined the culture of the Javanese, more specifically exploring a particular cultural value that is consensually believed by the Javanese. The researchers investigated what sayur lodeh is, what messages were contained in the purported order from the Sultan, and how the Javanese perceived them in the COVID-19 context. The researchers studied sayur lodeh and the context of when it was requested to be cooked, by whom it was requested to be cooked, how the food was served and eaten, and how the Javanese responded to the Sultan's recommendations.

There has been no scholarly article investigating the argument of sayur lodeh to repel an outbreak so far. Researching this idea provides an overview of how the Javanese reacted to a pandemic and how their beliefs impacted their decision-making in emergencies, health-related actions, and the everyday lives of the community. Thus, how local knowledge can be used, and the risk of material failure and loss of life can be minimized even further can be better understood.

\section{Methodology}

The researchers employed a qualitative content analysis as a method of inquiry. The researchers examined the presence, meanings, and relationships of words, themes, concepts, and context of the texts. The text observed was the poster containing instructions from the Sultan of Yogyakarta HB IX for cooking sayur lodeh, which was then refuted by the Office of Public Relations and Protocol of DIY that said the message was not from the Sultan himself. The researchers made inferences on the messages within the texts, the writer, the audience, and the culture and time of the text.

Krippendorf (1989) explained that content analysis was a method of studying substantive topics, messages, images, and voices. Content analysis is a research technique for drawing replicable and true inferences from texts to the contexts in which they are used. Content analysis offers new perspectives, improves a researcher's knowledge of complex phenomena, or encourages practical actions (Krippendorf, 1989). Texts, messages, and symbols do not speak for themselves. They can inform others. Texts provide meaning to particular circumstances, discourses, or intentions (Krippendorf, 1989, 2009). The information helps the reader choose between meanings and narrows the variety of otherwise available interpretations.

The poster was circulated using WA and social media (mostly Facebook and Twitter) at the beginning of the outbreak of COVID-19 in Indonesia (March 2020). The researchers looked at the context of the poster and what the message meant to the Javanese.

The study of the texts did not stop at interpreting the written words. It was also about how the message was sent, to whom, by whom, and for what reason. Texts do not have a single definition (Krippendorf, 1989, 2009). They can be interpreted from a wide range of viewpoints and 
can be subjected to some analyses. In this study, the researchers analyzed texts using Javanese cultural perspectives.

\section{Figure 1}

\section{Research Materials}

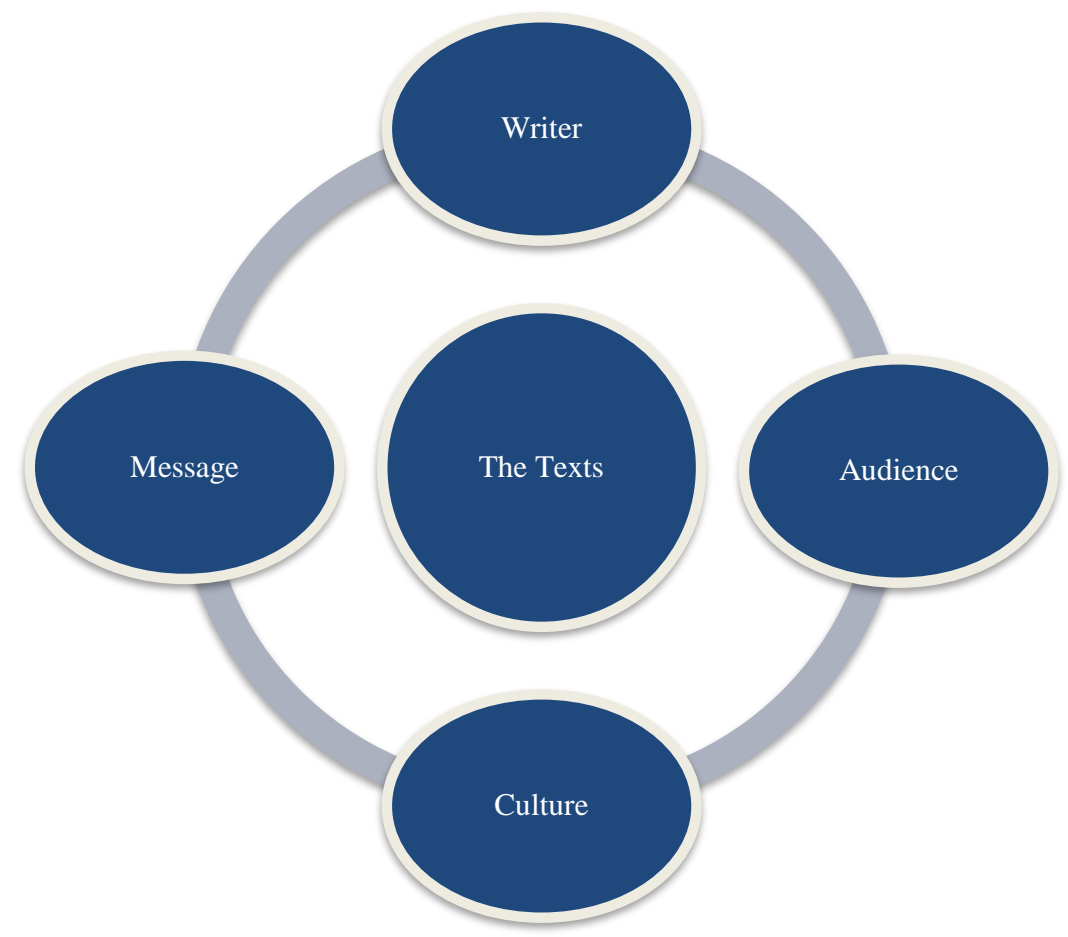

Experience is fundamental to the study of culture (Pickering, 2008). To gain a sense of culture, the researchers experienced buying the vegetables and ingredients for sayur lodeh following the instructions contained in the poster, inviting a Javanese cook to help to prepare the dish and cooking it, serving it for the family, and sharing it with some neighbors. One key trait of cultural studies is its focus on the subjective nature of social interactions, how specific social roles and processes are lived, how sense is made (Pickering, 2008). The researchers experienced a cultural practice and belief to collect the evidence and gain insight into the culture. Experience often means interpreting what happens in life, making our thoughts, emotions, and behavior meaningful (Pickering, 2008). Experiencing the ritual of sayur lodeh, its process, and the product was extremely valuable in informing the researchers how the ritual's social contexts are inhabited and understood. The researchers gained experience through constant, reflexive, and interpretive accounts of what happened.

The following (Figure 2) is an illustration of the design of this study. The design was adapted from Krippendorf's (1989) concept of content analysis and combined with Pickering's (2008) concept of cultural studies. The researchers examined the contexts, discourses, and purposes of the text. The research question led the researchers to understand the direction of the probable answer. The researchers analyzed the content and constructed the results of the study in an empirical manner. The findings are robust associations and conditions of contribution within the context of the text. 
Figure 2

Research Design

Research Questions: What is Sayur Lodeh? What message is in the texts that states sayur lodeh might repel a plaque, and how do the Javanese perceive these texts in the COVID-19 context?

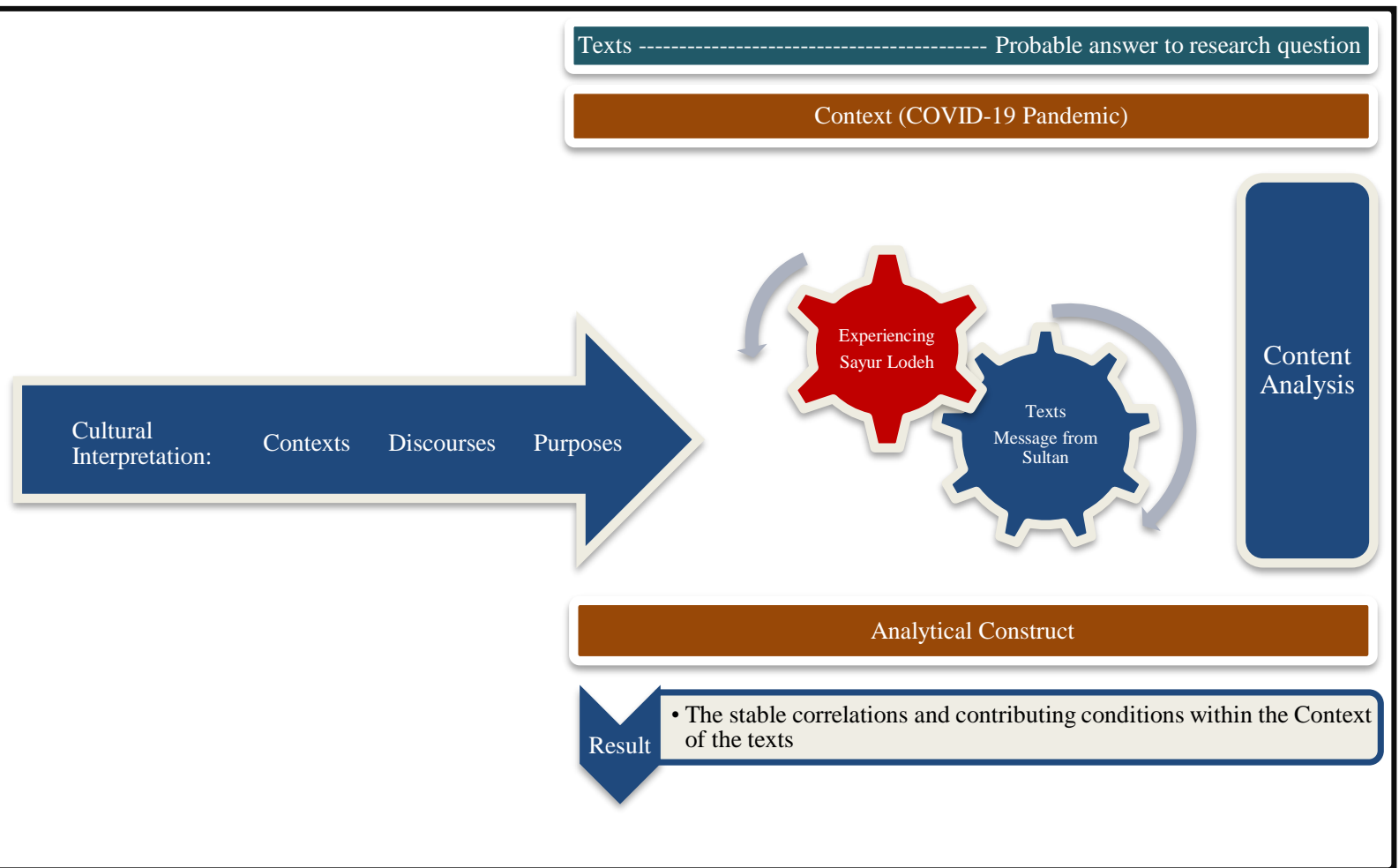

\section{Findings}

What is sayur lodeh, what message in the texts states that sayur lodeh might repel a plague, and how do the Javanese perceive these texts in the COVID-19 context. The study reveals three main assertions:

1) Sayur lodeh is a native Javanese dish stewed in coconut milk and containing various nutritious vegetables.

2) The call to cook sayur lodeh contains the sense of the high faith of Javanese people in the Sultan in difficult times, to be optimistic and to remain positive thinking, belief for a powerful union or togetherness in overcoming difficulties, and always asking for God's support.

3) The Javanese complied with the order to cook sayur lodeh, as most of them believed it could help them avoid misfortune. This belief has been passed from generation to generation since their ancestors.

\section{Sayur Lodeh is a nutritious traditional Javanese vegetable soup made with coconut milk}

Sayur lodeh is described in an article on detik.com (March 21, 2020) as a simple vegetable soup or curry made from seven main ingredients and coconut milk (Fitria, 2020). Sayur lodeh is a 
typical Central Javanese coconut milk dish. Usually, vegetables from the garden are processed into this vegetable curry (Sushmita, 2020). The article in detik.com also discusses the origins of sayur lodeh. Some scholars have argued that this practice dated back to the heyday of Central Javanese civilization in the 10th century. During the major eruption of Mount Merapi in 1006, sayur lodeh was proclaimed to be the answer to boost public faith that they would survive. Food historians such as Fadly Rahman studied sayur lodeh and concluded that the vegetables dated back to the 16th century after Spain and Portugal introduced long beans to Java. Others claim that it is an "old tradition" developed in the 19th century at the turn of the 20th century by the Yogyakarta intellectuals during the Indonesian National Awakening when many national myths were discovered, celebrated, and developed in different ways. The legend of sayur lodeh was reinforced in the early twentieth century. The most famous example came from 1931 when Java suffered from successive waves of the bubonic plague for more than two decades during the reign of Sultan HB VIII. However, records also indicate that sayur lodeh was cooked in response to crises in 1876, 1892, 1946, 1948, and 1951 (Fitria, 2020).

Sayur lodeh is now known not only to Javanese but to all Indonesians, Singaporeans, and Malaysians. In an attempt to describe sayur lodeh better, the researchers invited a 60-year-old Javanese cook to cook it with its original recipe. She cooked sayur lodeh from scratch, without any instant seasoning, using all fresh vegetables and herbs.

Figure 3

Cooking Sayur Lodeh
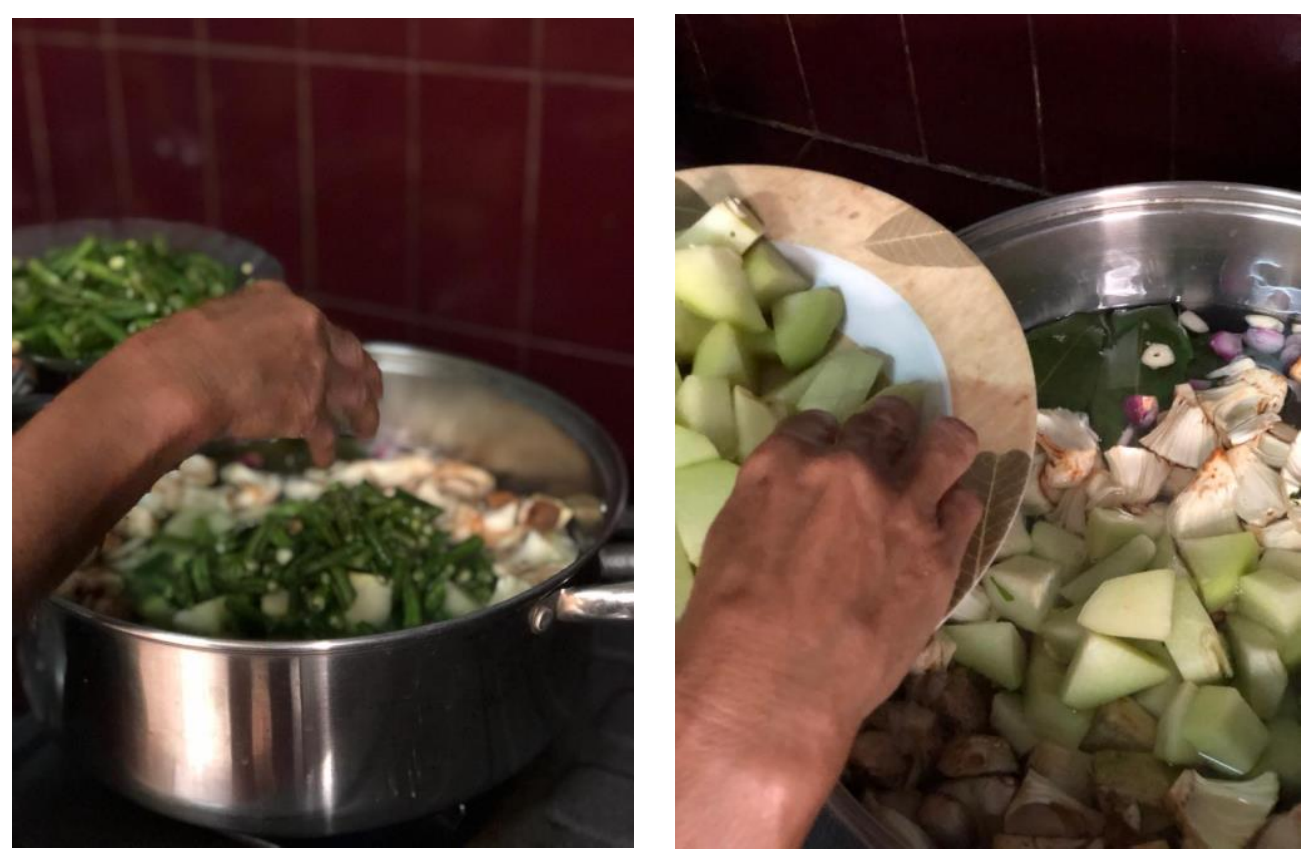

The most commonly used vegetables in traditional sayur lodeh are tomatoes, long beans, Chinese eggplants (purple eggplant), soybean tempeh, firm tofu, corn, cabbage, chayote, and melinjo. However, not all of these vegetables have to be included. All these vegetables should be cut to an edible size. The curry spices, all of which are ground into a paste, are shrimp paste, coriander, garlic, shallots, red chili peppers, ginger, galangal, and candlenuts. Other than that, coconut milk is one of the most significant ingredients. 
Figure 4

Sayur Lodeh-Ready to Eat

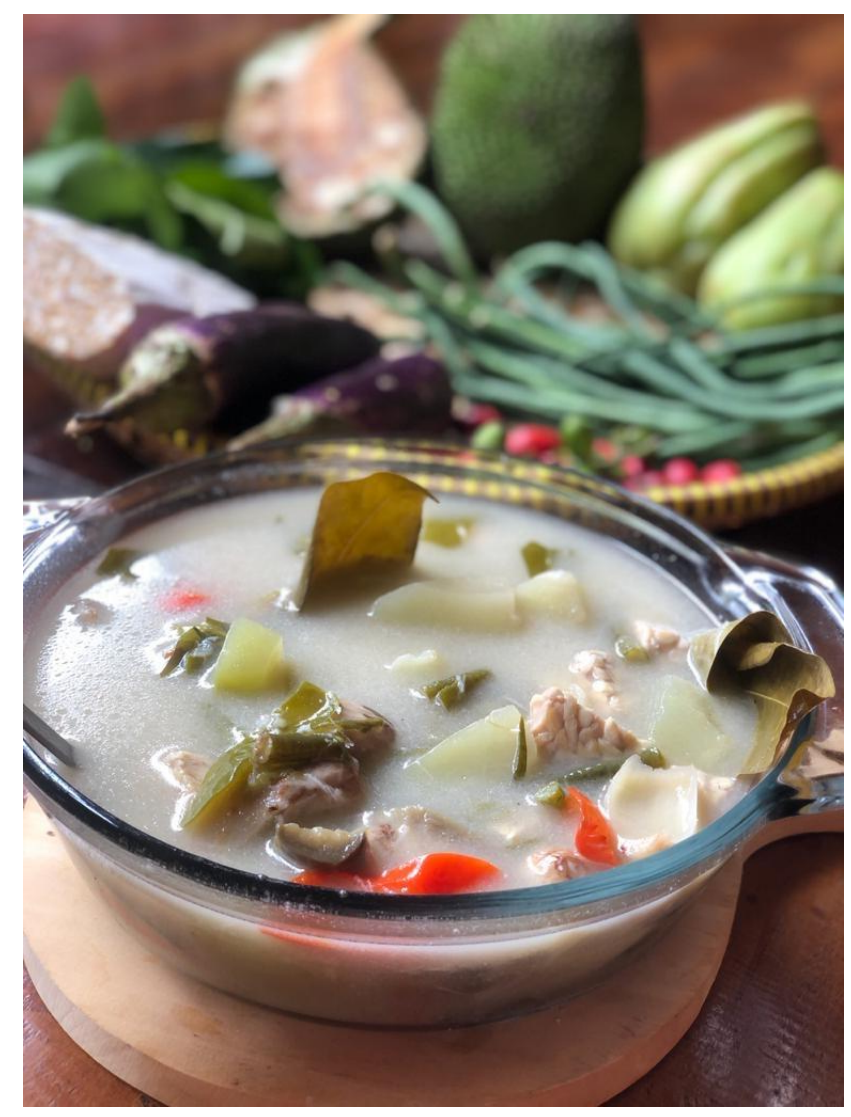

The researchers observed the cook preparing the meal. The oil was heated to medium-high heat in a soup pot. The spicy paste was fried until it was fragrant (about five minutes). She added daun salam (bay leaves) for an extra fragrance and stirred the curry for a minute. Then added coconut milk, water, seasoned with salt and palm sugar, and brought it to the boil. Then she added the cut vegetables, cooked to boil, then reduced the heat to simmer and cooked until the vegetables were fully cooked and tender. Then she switched off the heat, moved it to the serving bowl, and immediately served it with steamed white rice. Researchers ate the soup with the cook and the family. They were talking about the taste of sayur lodeh. The taste was as follows: sayur lodeh is tasty, fresh, and delicious. The coconut milk makes the food creamy and rich. The fragrance of the spices is appetizing. The dish is flavorful, and if the leftovers are heated, it will be thicker and more delicious.

The order to cook sayur lodeh indicates the Javanese people's high trust in the Sultan in difficult times, the hopeful and constructive attitude to the adversities, the unity to resolve difficulties, family support, and God's belief in moving forward

The message to cook sayur lodeh tujuh rupa, or sayur lodeh containing seven kinds of vegetables, was written in Javanese, and the virus's outbreak was referred to as "Pageblug Corona" (Fitria, 2020). The announcement was made attractively, a poster bearing a portrait of the King of Mataram, Yogyakarta Sultanate, Sri Sultan HB X. 


\section{Figure 5}

WA Message About Making Sayur Lodeh to Repel Coronavirus

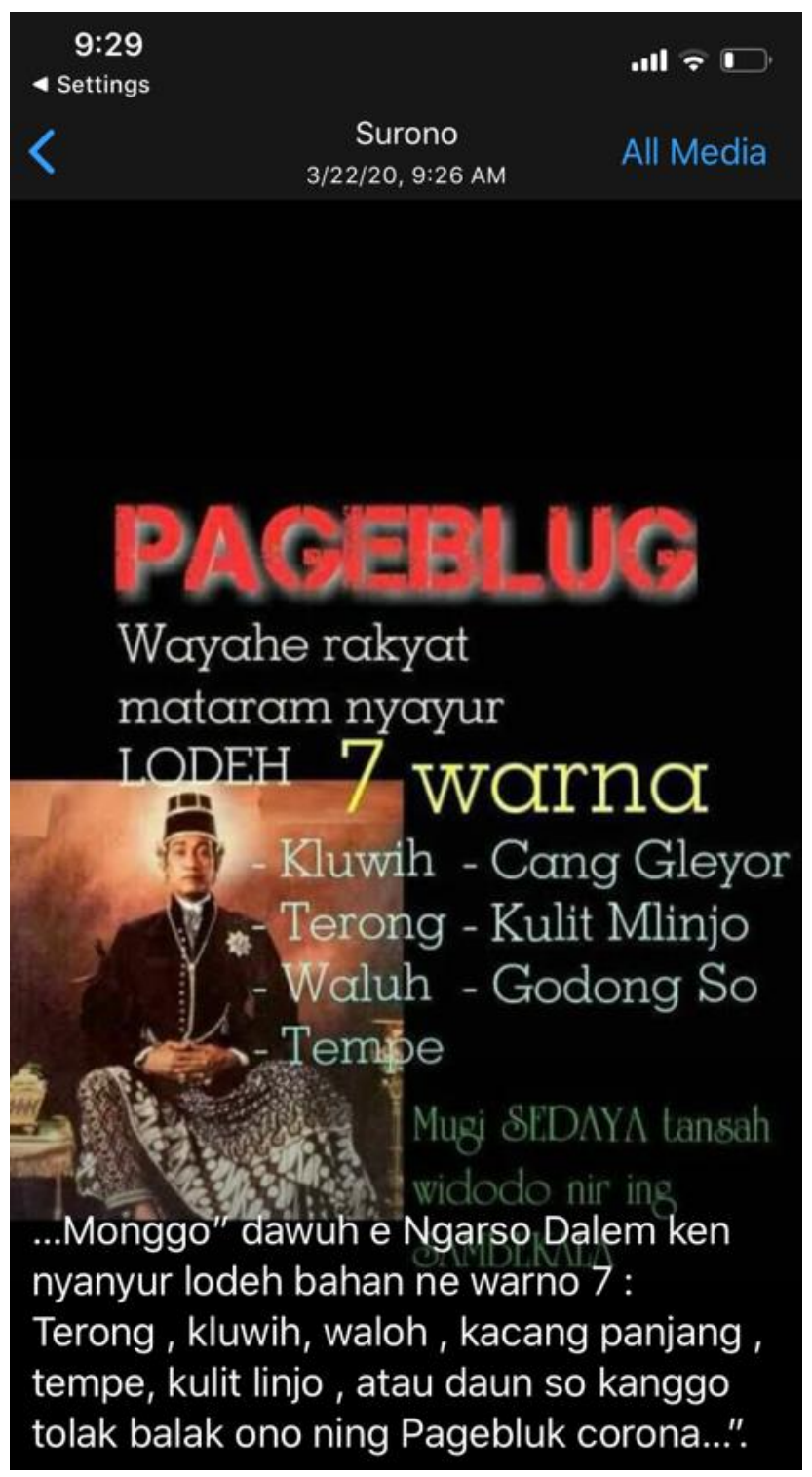

An inscription of the words of Ngarso Dalem or Sultan HB X accompanied the full-color poster. The contents of the message are: "Wayahe rakyat Mataram nyayur Lodeh 7 warna: Kluwih, Cang Gleyor, terong wungu, kulit mlinjo, waluh, godong so, tempe. mugi sedaya tansah widodo nir ing sambekala." This phrase means "Plague. It's time for the people of Mataram to make sayur lodeh in 7 colors: Kluwih, long beans, purple eggplant, melinjo, chayote, young melinjo leaves, and soybean tempeh."

Javanese food as a whole is rich in symbolism. Especially for pagebluk or the period to resist epidemics or calamities, it is recommended to cook sayur lodeh with seven vegetables. Seven vegetable or tujuh rupa in Bahasa Indonesia, has special meaning, seven or pitu in Javanese means pitulungan, which means asking for help (Sushmita, 2020). The Sultan's order to cook sayur lodeh 
was seen an impetus for social solidarity. Entire cities that cook the same things simultaneously create a strong sense of community (Suara Baru, 2020).

\section{Figure 6}

Seven Kinds of Ingredients for Sayur Lodeh (Six Vegetables and Soybean Tempeh)

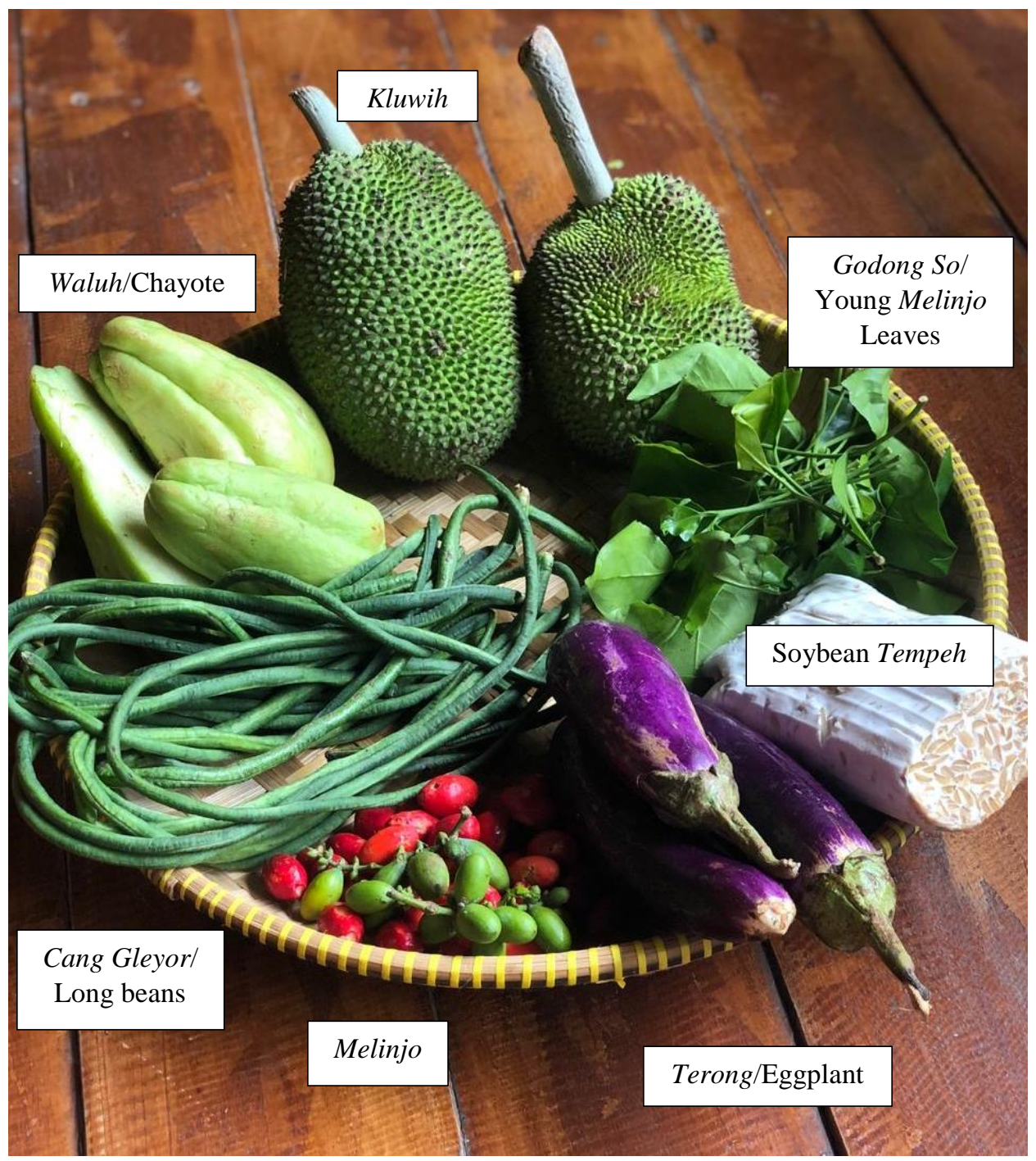

A Javanese culture teacher, Revianto Budi Santoso, clarified that sayur lodeh expands this symbolism linguistically and numerologically. Each of the seven main ingredients added to the base of coconut milk, melinjo, melinjo leaves, chayote, long beans, eggplant, jackfruit, and tempeh have a symbolic meaning derived from the sound of the syllable (Suara Baru, 2020). Wungu, in Javanese, means purple, from purple aubergine or eggplant, but it means also something like "bangun or alert/wake up," while lanjar from kacang lanjar (long bean) is the same as "berkah or blessing." Collect seven things, and you have got something more like a spell (Fitria, 2020). The researchers bought all of these seven ingredients for sayur lodeh tujuh rupa, as they needed to know each of the seven ingredients in the poster to experience the true taste of sayur lodeh. The cook helped to get the ingredients and cooked them until a delicious sayur lodeh was created. 


\section{Table 1}

Symbolic Meanings of Seven Vegetables for Sayur Lodeh

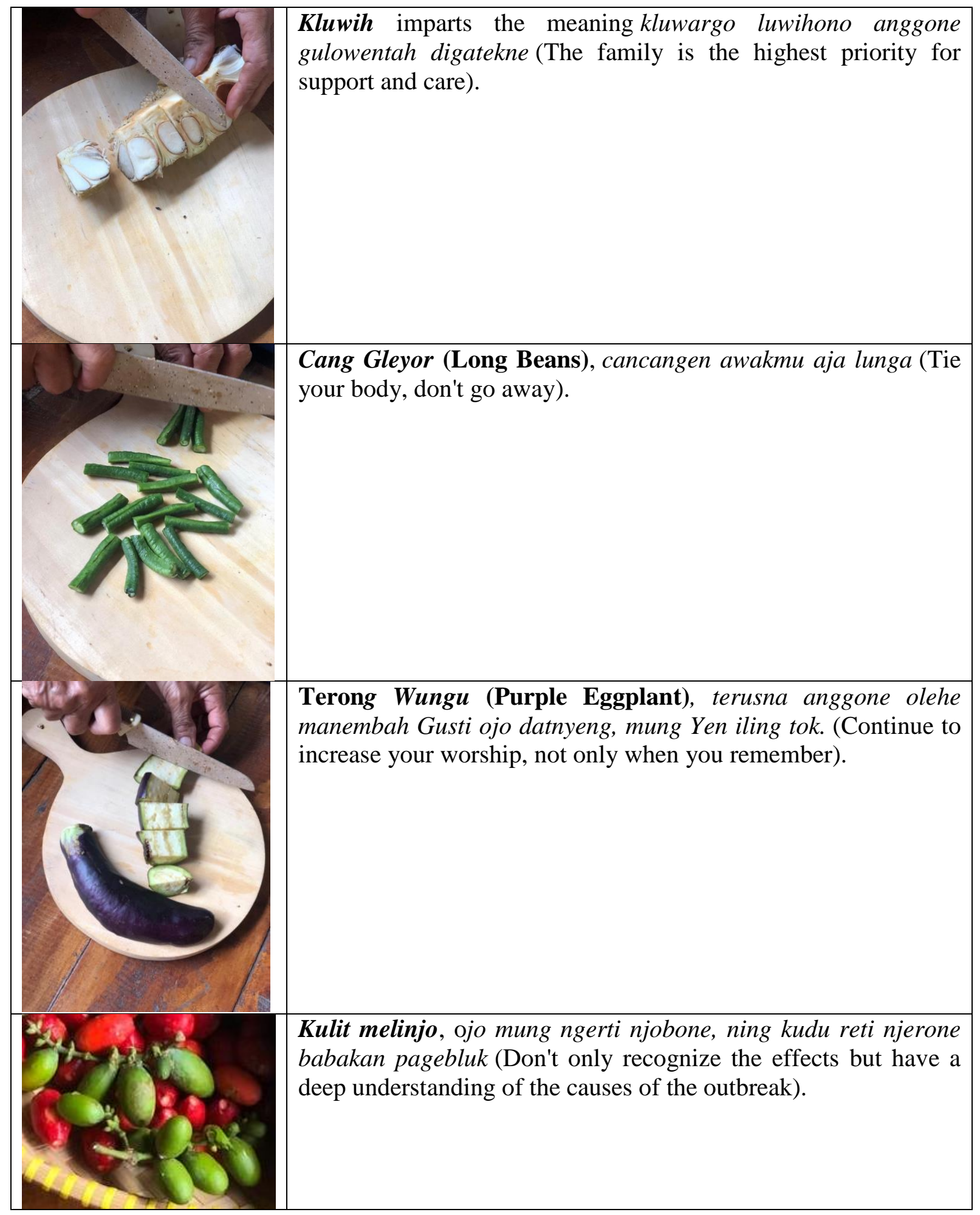




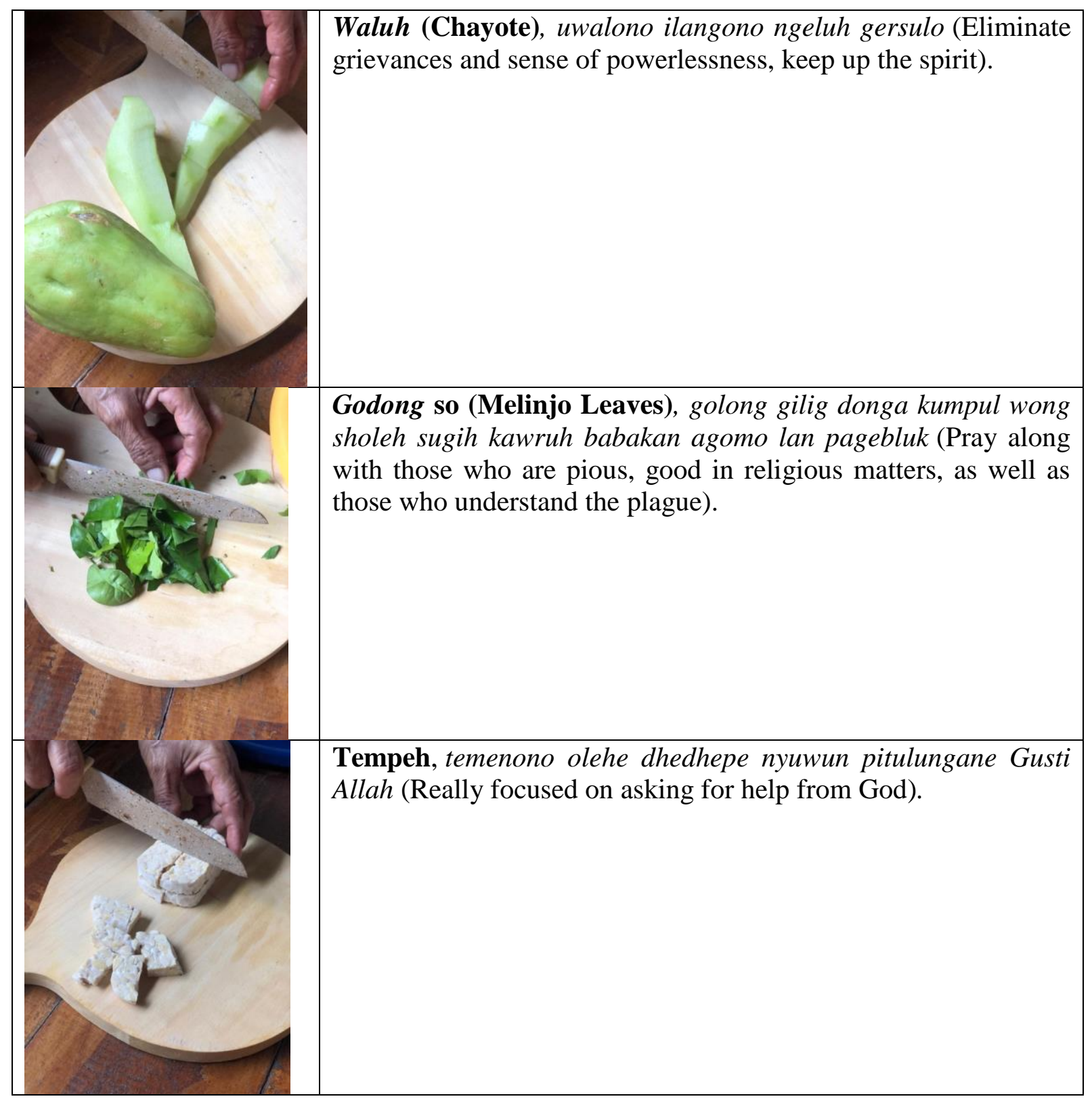

The Javanese cultural observer and the courtier of the Surakarta Palace, Kanjeng Raden Arya (KRA) Dr. Pranoto Adiningrat, M.M. (Suara Baru, 2020), who won the Cultural Star Award, claimed that the view that sayur lodeh is interpreted as a way of avoiding the pagebluk is a local wisdom. "It contains wise messages that we should always recall, surrender, and ask God. We're only taking the optimistic aspect."

The Javanese cooked sayur lodeh immediately, as most believe that it might help them escape misfortune. This assurance has been passed down from generation to generation

To understand the views of the Javanese people, the researchers gathered the opinions of cultural experts, palace members/officials, linguists, and the general public recorded in online newspapers. When the sayur lodeh cooking message was circulated between 21 to March 25, 2020, people went to the market to buy vegetables and ingredients for sayur lodeh. Sushmita (2020) of 
the Solo Post Daily wrote how seven different vegetables were hunted by buyers in several traditional markets in Klaten, Central Java. Sushmita quoted a statement from a vegetable seller at Klaten Main Market, "Today, the kluwih I sell is selling well. Many are looking for kluwih. I brought a bag (contains 50 kluwih). They sold out straight away. As a result, the price of kluwih multiplied in price. A vegetable with a prickly skin that typically sells for Rp. 5,000-Rp10,000 (3050 cents) per fruit, yet the price quickly increased to Rp. 15,000 (USD 1)."

The people of Yogyakarta and its surrounding areas consider the virus that causes COVID19 to be a catastrophe and have started to regard it as a pageblug or a decline in time (Ginting, 2020). Javanese people claim that the seven-colored sayur lodeh is thought to dismiss the bad luck of the coronavirus outbreak. Amid a modern society that is increasingly religious, some people followed the call through WA groups immediately without hesitation. As a result, the market and stalls were overwhelmed by women eager to buy the necessary ingredients (Siyasi, 2020).

Some village chiefs also arranged to eat sayur lodeh together. For example, after the circulation of a poster calling for the Sultan to cook sayur lodeh, all the village apparatus and the chief of the Gandekan Village (about 40 people) in the Jebres sub-district of Solo had a lunch of sayur lodeh in the village meeting center (Ariefana, 2020). They said that it was the order of the Mataram/Yogyakarta Palace and that it was effective in repelling the plague (Ginting, 2020) The message to cook sayur lodeh was considered a dawuh (command) by Ngarso Dalem, Sultan HB $\mathrm{X}$ (Siyasi, 2020). This activity contradicted the central government's order to ask people to stay at home and not to gather more than four people, particularly not to eat together.

Sushmita (2020), a journalist at the Solo Post (March 22, 2020), interviewed several vegetable vendors on the market. One interviewee was Suwarni, who said that his parents and ancestors used to cook sayur lodeh in the expectation that they would all be safe. "Javanese people typically serve this vegetable. Let's hope during the current situation, we could be bagas waras (stable, healthy, and strong). The disease epidemic could soon disappear," she said. The same thing was also explained by a seller of empon-empon (spices) at the Klaten Central Market, Fitri, 25. Since Saturday morning, a number of her customers had been looking for the 7-colored sayur lodeh ingredients. "Hmmm, I believe in and don't believe in the power of it. But I ate that dish before and would like to have more," she said

The order to cook sayur lodeh to keep away from Pageblug has also been followed by the Solo people since the time of their predecessors. The Solo Palace used to be joined by the Yogyakarta Palace during the rule of Mataram. The daughter of Pakoe Buwono XII, King of Solo Palace, GKR Wandansari Koesmortiyah, said that the people of Solo also believed in sayur lodeh and that the meaning of sayur lodeh was no different from that of the people of Yogyakarta. All kinds of vegetables in sayur lodeh have meaning and are a kind of request to God (Isha'an, 2020). One resident of Jatipuro Karanganyar, Solo, Yantini (60 years old), said that since ancient times her parents had always cooked sayur lodeh. This meal is thought to protect people in difficult times, particularly when there is a pageblug or an outbreak of disease. "Yes, some Javanese still believe in how sayur lodeh protect us in a precarious situation, not only now, but for a long time," she said. She hoped that all sorts of hazards could be eliminated and removed by cooking it. "Yes, one hopes that Allah will immediately get rid of Sengkolo (calamity) and any damage," she concluded (Isha'an, 2020).

Seven colored sayur lodeh is considered part of the Javanese tradition of disaster response (Hermawan, 2020). The message of cooking sayur lodeh to ward off the plague was also circulated via SMS in 2005. The message was in response to the hurricane in the South Sea at that time. Sultan HB X also denied that this was his order. "It's not my order to make sayur lodeh, but if the group 
obeys, what can we do," he said at the time. The cultural observer, Irfan Afifi, considered the behavior of the residents to be a form of traditional practice in responding to disasters. "This form of knowledge is conventional knowledge. [You] doesn't have to wait for the scientific confirmation," said Irfan (Hermawan, 2020). The people spontaneously cooked seven kinds of vegetables because of their belief. "It's enough to believe it or not, only to choose it. So, in this situation, science is no higher than tradition and belief," he said.

Javanese historian, Yoseph Kelik, claims that the message of the seven colors of vegetables and their meanings are part of the Javanese people's practice of tinkering or matching one thing to another (otak-atik gatuk dan cocok-cocokkan). There is no reference in Javanese historical literature to the seven-colored sayur lodeh dish. However, he said, "if you look closely, the message retains its own wisdom in coping with the outbreak of the Coronavirus. In addition to a range of foods, it can definitely provide protein and nutrition. Of course, there are more or less benefits of boosting the vitality of the body," he said. The viral message was so popular that it kept farmers and vegetable traders going. "Lower-level economies are moving in tough times because demand is still there,"' he added (Hermawan, 2020).

\section{Discussion and Conclusion}

Sayur lodeh contains a variety of nutritious vegetables. Nutritious food is also considered an antidote to disease, as during a pandemic. At the beginning of the growth of COVID-19 in Indonesia, the government spokesperson for COVID-19, Ahmad Yurianto, said at the Presidential Palace on October 3, 2020, that the Coronavirus could be prevented as long as the body's immune system or immunity was high. "Regarding herbs, we understand that our ancestors have known these herbs for centuries, and this is very, very nice for increasing immunity." He added that many traditional dishes in Indonesia contain lots of herbs or spices such as ginger, turmeric, etc. Indirectly, traditional cooking in Indonesia can potentially stop the Coronavirus. "Every day we eat traditional food, it is full of herbs. If we talk about sayur lodeh, that's herbal. Besides that, and kapau rice (mixed rice from Padang, West Sumatra), it also contains herbs and is good for increasing stamina. In kapau rice, not only herbs but also coconut milk, this is the wisdom of our ancestors" (Putri, 2020).

Preventive steps, such as the right food choice, will enable individuals to be protected from the risk of current infection from COVID-19 (Bhatta, 2020). Bhata's study results suggest that diet affects the immune strength to protect our body from pathogen attack (2020). Increasing the intake of nutrients will help strengthen the immune system and make individuals less vulnerable to disease, which is also considered a key factor in preventing viral infections such as COVID-19 (Wimalawansa, 2020). Halawa (2017) studied the relationship between the demographic features, food consumption patterns, and dietary-related health behaviors of the Chinese Han and Hui Ethnic Nationalities. Their study's findings emphasize that ethnicity, background, and some demographic characteristics can be directly associated with dietary habits and food consumption patterns of some of the ethnic groups. Individuals look at local plants from their home during the pandemic, seeking to improve immunity using the formula from their ancestors.

Alkhatib (2020) researched what functional food is ideal for speeding up healing and improving the immune system. Foods with antiviral properties are believed to include fruit, vegetables, fermented foods and probiotics, olive oil, fish, nuts and seeds, herbs, roots, fungi, amino acids, peptides, and cyclotides (Alkhatib, 2020). Alkhatib reviewed the report on key functional food plants with immunomodulatory and antiviral properties using data on medicinal food plants obtained and downloaded from English-language journals using online search engines. Functional food plants reported here may improve the immune system and cure respiratory tract infections and 
have a major effect on the general public's overall health. As many people worldwide are now bound to their homes, using these easily accessible plants in the daily diet will help improve the immune system and avoid SARS-CoV-2 infections. This could lower the risk of COVID-19 and facilitate speedy response in cases of SARS-CoV-2 infection (Alkhatib, 2020).

Herbal medicine is practiced in various countries. Mani et al. (2020) investigated papers in PubMed database on the use of traditional medicines, herbs, remedies or plants to cure infectious diseases, including coronavirus, SARS or MERS. Fifty five primary research papers have been identified. China, of course, is among the countries best known for developing herbal medicine. Chinese herbal medicine has played an important role in treating epidemic diseases and was commonly used to treat SARS patients almost two decades ago during the SARS epidemic, with confirmed protection and possible benefits. Traditional Chinese medicine has also been commonly used to treat cancer patients for a long period, is associated with immunomodulatory activity, and is used to treat coronavirus-related diseases (Huang et al., 2020). Herbal phytoconstituents are effective in reducing infectious conditions and were the only treatments available before antibiotics were introduced. Yang et al. (2020) recorded that more than $85 \%$ of patients infected with SARSCoV-2 in China had been treated with Traditional Chinese medicine. Traditional Chinese medicine can differentiate and treat the syndrome according to patients' clinical symptoms and is ideally able to avoid and control epidemics (Wang et al., 2020).

The use of natural products and phytomedicine continues to grow fast around the world, with many people nowadays reverting to such remedies in different national healthcare settings to treat various health challenges (World Health Organization, 2004). Mrid et al. (2020) investigated natural compounds in Moroccan medicinal plants that could be used as natural inhibitors of the novel coronavirus SARS-CoV-2, which causes coronavirus disease in 2019 (COVID-19). In their analysis, 29 Moroccan medicinal plants contained at least three of these coronavirus inhibitors. Therefore, the medicinal plants selected in this study can contain direct anti-SARS-CoV-2 compounds. Aanouz et al. (2020) conducted research to decide if natural origin components have an antiviral effect and prevent humans from being infected with this Coronavirus using the most effective approach is molecular docking. Docking has shown that among 67 molecules of natural origin, three molecules (Crocin, Digitoxigenin, and $\beta$-Eudesmol) are proposed as coronavirus inhibitors based on the energy form of interaction between these molecules and the protein studied.

The call to cook sayur lodeh contains a sense of the high confidence of the people of Java in the Sultan in challenging times. The Sultan of Yogyakarta is both a cultural leader and a formal ruler (governor). He plays an important role in mobilizing people, uniting, and taking action during calamities. This study shows how eager the Javanese people were to do what Sultan has asked to repel Coronavirus. Later, they found out that the order was not from the Sultan, yet the natives and residents of Yogyakarta love and trust their Sultan. In an emergency and a pandemic, revered cultural leaders may be active in implementing steps to resolve the crisis, set an example, and lead the people. Dziva (2020) researched the ability of traditional leaders to localize the battle against Coronavirus in rural Zimbabwe. Their study shows that leaders and their decentralized systems depend on community mobilization, awareness-raising, dispelling pandemic rumors and misconceptions, using vaccinations, and pressing for the compromise of steps incompatible with local customs, cultural values, and norms. The article calls for the resourcing and preparation of traditional leaders to effectively realize their potential in fighting COVID-19 in rural areas.

The message of cooking sayur lodeh to repel the plague also underlines the importance of keeping people calm, optimistic, and positive. Optimism and mastery are two cognitive characteristics that include optimistic aspirations for the future and are significant predictors of 
reduced anxiety and superior coping and physical health in many populations, including cancer survivors (Gallagher et al., 2019). Galagher et al. (2019) investigated the particular consequences of these characteristics. Their cross-sectional research used structural equation modeling to analyze the particular effects of optimism and mastery on emotion, coping, and well-being in 603 adult cancer survivors and whether the findings were consistent in both men and women. The results showed that both optimism and mastery were correlated with enhanced emotion, coping, and wellbeing, and together accounted for a small to moderate variance. Optimism and positive thinking encourage positive emotions, perceptions, and interactions to enhance health and well-being (Aspinwall \& Tedeschi, 2010). Optimism was found to be three-dimensional, including outcome expectations, efficacy expectations, and unrealistic thinking; optimistic patients could handle chronic disease better (Fournier et al., 1999). Optimism and physical well-being are very closely related (Scheier \& Carver, 2018).

The texts also stress the importance of a strong union or unity and family support in resolving difficulties and always asking for God's blessing. Mosavel et al. (2015) examined how low-income, urbanized communities in South Africa are subjected to high levels of everyday stressors that increase their vulnerability to negative outcomes. Resilience can provide opportunities for young people to conquer adversity and can lead to their positive growth. The study found that group connectivity, optimism, and altruism were prevalent in youth responses and could promote community and individual resilience. Johnson-Garner and Meyers (2003) studied African-American children who overcome hardship to adapt successfully. They found that the support provided to children by an extended family was beneficial and encouraged positive child outcomes. Togetherness is the secret to being resilient. During this pandemic, to remain physically safe, people need to remain optimistic; and the message about sayur lodeh indicates this.

The message of cooking sayur lodeh also points out that people need to seek God's aid to believe that God will protect them. Some recent studies have revealed the multiple beneficial effects of faith on those who are in crisis. A study of cancer patients showed that those who felt a stronger relation to faith and spirituality had improved physical health (Jim et al., 2015). Religiosity has been correlated with better compliance with dialysis for those in Saudi Arabia; Hindu identification in India has been related to stress management skills, and religious women in Thailand control diabetes more effectively than those who do not identify with a religion (Wiederhold, 2020). In all situations and places, faith allows people to deal with their lives' challenges, both big and small. Then, it makes sense that those who use faith and spirituality to cope with crises will turn to the same assistance during the coronavirus pandemic of 2019. According to an analysis of the search results from 95 countries, as the virus started to spread aggressively across the world in March of this year, the number of Google prayer searches increased exponentially (Masters \& Spielmans, 2007). The Javanese cook sayur lodeh and feel connected to their faith by following the culinary symbols and the text.

The Javanese replied to the order to cook sayur lodeh immediately. Most of them believe that sayur lodeh might help them escape misfortune. This belief has been held from generation to generation since the time of their ancestors. A Javanese meal ritual known as slametan is full of symbols (Newberry, 2007). The food consumed, the procedure, and the people involved in planning and interaction are an essential whole. Javanese slametan, a communal ritual meal, brings neighbors, friends, and communities together to restore balance and harmony between the Javanese community's visible and unseen realms (Jakl, 2019). Even though there was a government restriction against gathering together due to Coronavirus, the Javanese saw the ritual of eating together as one way of balancing and getting the world into peace with a slametan with sayur lodeh they kept doing the ritual. The Javanese slametan can be traced back to the pre-Islamic, participatory animal sacrifice (Jakl, 2019) 
The researchers were unable to obtain data directly from community sources owing to large-scale social limitations. COVID-19 has transformed the way research is conducted (Lourenco \& Tasimi, 2020; Dodds \& Hess, 2020; Sy et al., 2020). This limitation leads to a suggestion for further study to investigate how common Javanese people understood the order to cook sayur lodeh and their interpretation of the message. More research is needed to examine other local wisdom and social responses to certain situations. It is also important to develop how the principles extracted from this research can be used as guidance for the implementation of policies, in particular those related to the role of cultural and community leaders in the prevention of infectious diseases or other disasters.

\section{Funding Details}

This work was supported by the BOPTN UIN Syarif Hidayatullah Jakarta under Grant UN.01/KPA/1346/2020.

\section{Disclosure Statement}

The authors declare that they have no competing financial interests or personal relationships that could have appeared to influence the work reported in this paper

\section{References}

Aanouz, I., Belhassan, A., El-Khatabi, K., Lakhlifi, T., El-ldrissi, M., \& Bouachrine, M. (2020). Moroccan medicinal plants as inhibitors against SARS-CoV-2 main protease: Computational investigations. Journal of Biomolecular Structure \& Dynamics. https://doi.org/10.1080/07391102.2020.1758790

Abdullah, I. (2020). COVID-19: Threat and fear in Indonesia. Psychological Trauma: Theory, Research, Practice, \& Policy, 12(5), 488-490. https://doi.org/10.1037/tra0000878

Airhihenbuwa, C. O., Iwelunmor, J., Munodawafa, D., Ford, C. L., Oni, T., Agyemang, C., Mota, C., Ikuomola, O. B., Simbayi, L., Fallah, M. P., Qian, Z., Makinwa, B., Niang, C., \& Okosun, I. (2020). Culture matters in communicating the global response to COVID-19. Preventing Chronic Disease, 17, 200245. https://doi.org/10.5888/pcd17.200245

Alkhatib, A. (2020). Antiviral functional foods and exercise lifestyle prevention of Coronavirus. Nutrients, 12(9), 2633. https://doi.org/10.3390/nu12092633

Ananta, A., Arifin, E. N., \& Hasbullah, M. S. (2015). Demography of Indonesia's ethnicity. ISEAS-Yusof Ishak Institute Singapore. https://doi.org/10.1355/9789814519885

Ang, L., Lee, H. W., Choi, J. Y., Zhang, J., \& Lee, M. S. (2020). Herbal medicine and pattern identification for treating COVID-19: A rapid review of guidelines. Integrative Medicine Research, 9(2), 100407. https://doi.org/10.1016/j.imr.2020.100407

Ariefana, P. (2020, March 21). Tradisi tolak bala virus corona dengan sarapan sayur lodeh, apakah ampuh? [The tradition of rejecting corona virus with lodeh vegetable breakfast, is it effective?]. Solopos. https://jateng.suara.com/read/2020/03/24/064500/tradisi-tolakbala-virus-corona-dengan-sarapan-sayur-lodeh-apakah-ampuh?page=all

Aspinwall, L. G., \& Tedeschi, R. G. (2010). The value of positive psychology for health psychology: Progress and pitfalls in examining the relation of positive phenomena to health. Annals of Behavioral Medicine, 39(1), 4-15. https://doi.org/10.1007/s12160-009-9153-0 
Bhatta, A. (2020). Choice of food: A preventive measure during Covid-19 outbreak. Europasian Journal of Medical Sciences, 2(1), 85-89. https://doi.org/10.46405/ejms.v2i1.49

Buduneli, N. (2020). What has COVID-19 taken from us and brought instead? Oral Diseases, odi.13446. Advance online publication. https://doi.org/10.1111/odi.13446

Burhan, E., Syam, A. F., Rahyussalim, A. J., Prasenohadi, P., Wulung, N. G. L., Susanto, A. D., Sajinadiyasa, I. G. K., Puspitorini, D., Lestari, D., Widyahening, I. S., Setiawaty, V., Ocviyanti, D., Putri, K. Q., Guntara, A., Rianda, D., Shankar, A. H., \& Agustina, R. (2020). The emergence of COVID-19 in Indonesia: Analysis of predictors of infection and mortality using independent and clustered data approaches. MedRxiv, 2020.07.10.20147942. https://doi.org/10.1101/2020.07.10.20147942

Central Bureau of Statistics of the Republic of Indonesia. (2015). Mengulik Data Suku di Indonesia [Ethnic Groups in Indonesia]. https:/www.bps.go.id/news/2015/11/18/127/mengulik-datasuku-di-indonesia.html

Cohen, S., Janicki-Deverts, D., \& Miller, G. E. (2007). Psychological stress and disease. JAMA, 298(14), 1685-1687. https://doi.org/10.1001/jama.298.14.1685

Daghfous, N., Petrof, J. V., \& Pons, F. (1999). Values and adoption of innovations: A cross-cultural study. Journal of Consumer Marketing, 16(4), 314-331. https://doi.org/10.1108/ 07363769910277102

Dein, S., Loewenthal, K., Lewis, C. A., \& Pargament, K. I. (2020). COVID-19, mental health and religion: An agenda for future research. Mental Health, Religion \& Culture, 23(1), 1-9. https://doi.org/10.1080/13674676.2020.1768725

Dodds, S., \& Hess, A. C. (2020). Adapting research methodology during COVID-19: Lessons for transformative service research. Journal of Service Management: Vol. ahead-of-p (Issue ahead-of-print). https://doi.org/10.1108/JOSM-05-2020-0153

Dziva, C. (2020). Prospects and challenges for traditional leaders in combating COVID-19 pandemic in rural Zimbabwe. SSRN Electronic Journal. https://doi.org/10.2139/ssrn.3599770

Elmira, P. (2020, May 18). Legenda sayur lodeh yang dipercaya bisa mengusir wabah [The legend of sayur lodeh to repel plague]. Liputan Enam. Retrieved October 20, 2020, from https://www.liputan6.com/lifestyle/read/4257103/legenda-sayur-lodeh-yang-dipercayabisa-mengusir-wabah

Fitria, R. (2020, March 27). Sayur lodeh 7 rupa untuk tangkal Virus Corona? Ini Penjelasannya [Sayur lodeh with 7 kinds of vegetables to repel Coronavirus? An explanation]. Detik.

Fournier, M., de Ridder, D., \& Bensing, J. (1999). Optimism and adaptation to multiple sclerosis: What does optimism mean? Journal of Behavioral Medicine, 22(4), 303-326. https://doi.org/10.1023/A:1018776618323

Gallagher, M. W., Long, L. J., Richardson, A., \& D’Souza, J. M. (2019). Resilience and coping in cancer survivors: The unique effects of optimism and mastery. Cognitive Therapy and Research, 43(1), 32-44. https://doi.org/10.1007/s10608-018-9975-9

Garbe, A., Ogurlu, U., Logan, N., \& Cook, P. (2020). Parents' Experiences with Remote Education during COVID-19 School Closures. American Journal of Qualitative Research, 4(3), 4565. https://doi.org/10.29333/ajqr/8471

Garrett, L. (2020). COVID-19: the medium is the message. The Lancet, 395(10228), 942-943. https://doi.org/10.1016/S0140-6736(20)30600-0

Geertz, C. (1964). The religion of Java. Free Press.

Ginting, J. (2020, March 21). Bagian dari tradisi saat hadapi bencana, warga Jogja bikin sayur lodeh 7 warna [Part of tradition when facing disasters, Jogja residents make 7-color sayur 
lodeh]. Riau Online. https://www.riauonline.co.id/nasional/read/2020/03/21/bagian-daritradisi-saat-hadapi-bencana-warga-jogja-bikin-sayur-lodeh-7-warna

Goldberg, J. F. (2020). Psychiatry's Niche Role in the COVID-19 Pandemic. The Journal of Clinical Psychiatry, 81(3). https://doi.org/10.4088/JCP.20com13363

Hakam, A. (2017). Communal feast slametan: Belief system, ritual, and the ideal of Javanese society. Hayula Indonesian Journal of Multidisciplinary Islamic Studies, 1(1), 97-111.

Halawa, A. (2017). Association between ethnicity and dietary behaviors in Chinese Han and Hui nationalities. Journal of Ethnic and Cultural Studies, 4(2), 65-80. https://doi.org/10.29333/ejecs/75

Hamzah, (2020). Civil Law Agreement and Its Implication on Regulation for Prevention of Corruption within Covid-19 Pandemic. Journal of Social Studies Education Research, 11(3), 156-176. Retrieved from https://jsser.org/index.php/jsser/article/view/2609/464

Hermawan, A. (2020, March 21). Sayur lodeh 7 warna ala warga Yogya kala pagebluk corona [7 color lodeh vegetables ala Yogya residents during pagebluk corona]. Gatra. https://www.gatra.com/detail/news/472843/gaya-hidup/sayur-lodeh-7-warna-ala-wargayogya-kala-pagebluk-corona

Hisham, I. N., Townsend, G., Gillard, S., Debnath, B., \& Sin, J. (2020). COVID-19: The perfect vector for a mental health epidemic. BJPsych Bulletin, 1-7. https://doi.org/10.1192/bjb.2020.60

Holmes, E. A., O'Connor, R. C., Perry, V. H., Tracey, I., Wessely, S., Arseneault, L., Ballard, C., Christensen, H., Cohen Silver, R., Everall, I., Ford, T., John, A., Kabir, T., King, K., Madan, I., Michie, S., Przybylski, A. K., Shafran, R., Sweeney, A., ... Bullmore, E. (2020). Multidisciplinary research priorities for the COVID-19 pandemic: A call for action for mental health science. The Lancet Psychiatry, 7(6), 547-560. https://doi.org/10.1016/S2215-0366(20)30168-1

Huang, J., Wu, L., Ren, X., Wu, X., Chen, Y., Ran, G., Huang, A., Huang, L., \& Zhong, D. (2020). Traditional Chinese medicine for corona virus disease 2019. Medicine, 99(35), e21774. https://doi.org/10.1097/MD.0000000000021774

Isha'an, M. (2020, March 22). Tolak bala pagebluk corona, warga Solo ramai-ramai nyayur lodeh [Against pagebluk corona outbreak, Solo residents cook lodeh vegetables]. RRI. Retrieved October 21, 2020, from https://rri.co.id/surakarta/daerah/805639/tolak-bala-pageblukcorona-warga-solo-ramai-ramai-nyayur-lodeh

Jakl, J. (2019). Cooking for demons, soldiers, and commoners. In C. Leong-Salobir (Ed.), Routledge handbook of food in Asia. https://doi.org/10.4324/9781315617916-9

Jim, H. S. L., Pustejovsky, J. E., Park, C. L., Danhauer, S. C., Sherman, A. C., Fitchett, G., Merluzzi, T. V., Munoz, A. R., George, L., Snyder, M. A., \& Salsman, J. M. (2015). Religion, spirituality, and physical health in cancer patients: A meta-analysis. Cancer, 121(21), 3760-3768. https://doi.org/10.1002/cncr.29353

Johnson-Garner, M. Y., \& Meyers, S. A. (2003). What factors contribute to the resilience of African-American children within kinship care? Child and Youth Care Forum, 32(5), 255269. https://doi.org/10.1023/A:1025883726991

Kastanakis, M. N., \& Voyer, B. G. (2014). The effect of culture on perception and cognition: A conceptual framework. Journal of Business Research, 67(4), 425-433. https://doi.org/10.1016/j.jbusres.2013.03.028 
Krippendorf, K. (1989). Content analysis: An introduction to its methodology. In E. Barnouw, G. Gerbner, W. Schramm, T. L. Worth, \& L. Gross (Eds.), International encyclopedia of communication (Vol. 1, pp. 403-407). Oxford University Press.

Krippendorf, K. (2009). Testing the reliability of content analysis data: What is involved and why. In K. Krippendorf \& M.A. Bock (Eds.), The content analysis reader (pp. 350-357). SAGE Publications.

Lazzari, C., Shoka, A., Nusair, A., \& Rabottini, M. (2020). Psychiatry in time of COVID-19 pandemic. Psychiatria Danubina, 32(2), 229-235. https://doi.org/10.24869/psyd.2020.229

Lestari, P.M., Djatmika, Sumarlam \& Purnanto, D. (2019). Javanese Women's Political Discourse in Response to the 2019 Indonesian General Election. Journal of Social Studies Education Research, 10(3), 193-211.

Li, D., \& Lau, C. (2020). Combating COVID-19: East meets West. British Journal of General Practice, 70(696), e442-e443. https://doi.org/10.3399/bjgp20X710753

Lourenco, S. F., \& Tasimi, A. (2020). No participant left behind: Conducting science during COVID-19. Trends in Cognitive Sciences, 24(8), 583-584. https://doi.org/https://doi.org/10.1016/j.tics.2020.05.003

Malai, V., \& Speece, M. (2005). Cultural impact on the relationship among perceived service quality, brand name value, and customer loyalty. Journal of International Consumer Marketing, 17(4), 7-39. https://doi.org/10.1300/J046v17n04_02

Mani, J. S., Johnson, J. B., Steel, J. C., Broszczak, D. A., Neilsen, P. M., Walsh, K. B., \& Naiker, M. (2020). Natural product-derived phytochemicals as potential agents against $\begin{array}{lllll}\text { coronaviruses: A review. Virus Research, 284, } 197989 . & .\end{array}$ https://doi.org/10.1016/j.virusres.2020.197989

Masters, K. S., \& Spielmans, G. I. (2007). Prayer and health: Review, meta-analysis, and research agenda. Journal of Behavioral Medicine, 30, 329-338. https://doi.org/10.1007/s10865-0079106-7

McCorkle, W. (2020). Problematizing Immigration Restrictions during COVID-19 in the Social Studies Classroom. Research in Social Sciences and Technology, 5(3), 1-24. https://doi.org/10.46303/ressat.05.03.1

Mian, A., \& Khan, S. (2020). Coronavirus: The spread of misinformation. BMC Medicine, 18(1), 89. https://doi.org/10.1186/s12916-020-01556-3

Mosavel, M., Ahmed, R., Ports, K. A., \& Simon, C. (2015). South African, urban youth narratives: Resilience within community. International Journal of Adolescence and Youth, 20(2), 245255. https://doi.org/10.1080/02673843.2013.785439

Mrid, R. B., Bouchmaa, N., Kabach, I., Sobeh, M., Zyad, A., Nhiri, M., \& Yasri, A. (2020). In silico screening of Moroccan medicinal plants with the ability to directly inhibit the novel Coronavirus, SARS-CoV-2. Research Square. https://doi.org/10.21203/rs.3.rs-38104/v1

Muqoddam, F., \& Maghfiroh, V. S. (2019). Syncretism of Slametan tradition as a pillar of Islam Nusantara. Karsa: Journal of Social and Islamic Culture, 27(1), 75-93. https://doi.org/10.19105/karsa.v27i1.1950

Muryanto, B. (2020, March 19). COVID-19: Yogyakarta announces UGM professor as second confirmed case. The Jakarta Post. https://www.thejakartapost.com/news/2020/03/19/covid19-yogyakarta-announces-ugm-professor-as-second-confirmed-case.html

Nasir, M. A. (2019). Revisiting the Javanese Muslim Slametan: Islam, local tradition, honor and symbolic communication. Al-Jami'ah: Journal of Islamic Studies, 57(2), 329-358. https://doi.org/10.14421/ajis.2019.572.329-358 
Ncube, S., \& Motalenyane, A. M. (2020). Social Distancing, Cultural and Psychological Effects on Learners in a Rural Setting in Zimbabwe. Journal of Ethnic and Cultural Studies, 7(3), 200-209. http://dx.doi.org/10.29333/ejecs/503

Newberry, J. (2007). Rituals of rule in the administered community: The Javanese Slametan reconsidered. Modern Asian Studies, 41(6), 1295-1329. https://doi.org/10.1017/ S0026749X06002575

Pickering, M. (2008). Experience and the social world. In M. Pickering (Ed.), Research methods for cultural studies (pp. 17-31). Edinburgh University Press.

Platto, S., Xue, T., \& Carafoli, E. (2020). COVID19: An announced pandemic. Cell Death \& Disease, 11(9), Article 799. https://doi.org/10.1038/s41419-020-02995-9

Putri, C. A. (2020, March 10). Kemenkes: Sayur lodeh \& nasi kapau bisa tangkal corona [Ministry of Health: Sayur lodeh \& kapau rice can prevent corona]. CNBC Indonesia. https://www.cnbcindonesia.com/lifestyle/20200310152940-33-143817/kemenkes-sayurlodeh-nasi-kapau-bisa-tangkal-corona

Rasyid, S. (2020, March 23). Tak relevan dengan zaman, sayur "tolak bala" bisa tangkal Corona tuai pro kontra [Irrelevant to the age, vegetables "reject bala" can prevent corona reaping pros cons]. Merdeka. Retrieved October 21, 2020, from https://www.merdeka.com/jateng/pro-kontra-sayur-tolak-bala-penangkal-corona-bisausir-wabah-sampai-tak-lagi-relevan.html

Remuzzi, A., \& Remuzzi, G. (2020). COVID-19 and Italy: What next? The Lancet, 395(10231), 1225-1228. https://doi.org/10.1016/S0140-6736(20)30627-9

Ren, J., Zhang, A.-H., \& Wang, X.-J. (2020). Traditional Chinese medicine for COVID-19 treatment. Pharmacological Research, 155, Article 104743. https://doi.org/10.1016/ j.phrs. 2020.104743

Retrieved from https://jsser.org/index.php/jsser/article/view/1214/394

Ricklefs, M. C. (2006). Mystic synthesis in Java: A history of Islamization from the fourteenth to the early nineteenth. EastBridge.

Rustan, A.S (2020). Communication through Indonesian Social Media: Avoiding Hate Speeches, Intolerance, and Hoaxes Journal of Social Studies Education Research, 11(2), 174--185. Retrieved from https://jsser.org/index.php/jsser/article/view/2314/452

Scheier, M. F., \& Carver, C. S. (2018). Dispositional optimism and physical health: A long look back, a quick look forward. American Psychologist, 73(9), 1082-1094. https://doi.org/10.1037/amp0000384

Shavitt, S., \& Barnes, A. J. (2018). Cross-cultural consumer psychology. Consumer Psychology Review. https://doi.org/10.1002/arcp.1047

Shigemura, J., Ursano, R. J., Morganstein, J. C., Kurosawa, M., \& Benedek, D. M. (2020). Public responses to the novel 2019 coronavirus $(2019-\mathrm{nCoV})$ in Japan: Mental health consequences and target populations. Psychiatry and Clinical Neurosciences, 74(4), 281282. https://doi.org/10.1111/pcn.12988

Sikhangezile, N., \& Modise, M. A. (2020). Social distancing, cultural and psychological effects on learners in a rural setting in Zimbabwe. Journal of Ethnic and Cultural Studies, 7(3), 200209.

Siyasi, T. (2020, March 23). The power of sayur lodeh tujuh warna: Betulkah mampu sebagai tolak bala corona? [The power of sayur lodeh seven colors: Is it really able to resist coronavirus?]. Tintasiyasi. https://www.tintasiyasi.com/2020/03/the-power-of-sayurlodeh-tujuh-warna.html 
Spinelli, A., \& Pellino, G. (2020). COVID-19 pandemic: Perspectives on an unfolding crisis. British Journal of Surgery, 107(7), 785-787. https://doi.org/10.1002/bjs.11627

Spoorthy, M. S., Pratapa, S. K., \& Mahant, S. (2020). Mental health problems faced by healthcare workers due to the COVID-19 pandemic-A review. Asian Journal of Psychiatry, 51, Article 102119. https://doi.org/10.1016/j.ajp.2020.102119

Strunc, A. (2019). The Politics of Culture. Journal of Culture and Values in Education, 2(1), 7180. https://doi.org/10.46303/jcve.02.01.6

Suara Baru. (2020, March 22). Heboh lodeh tujuh warna penolak pagebluk corona [Viral lodeh seven colors to repel coronavirus. Suara Baru.

Sushmita, C. I. (2020, March 21). Bahan wayur lodeh 72 arna jadi buruan warga Klaten, liklaim mampu tolak bala [Klaten residents search for Lodeh 7-colored vegetable ingredients, alleged to be able to withstand outbreaks]. Solopos. Retrieved October 21, 2020, from https://www.solopos.com/bahan-sayur-lodeh-7-warna-jadi-buruan-warga-klaten-diklaimmampu-tolak-bala-1053099

Sy, M., O’Leary, N., Nagraj, S., El-Awaisi, A., O’Carroll, V., \& Xyrichis, A. (2020). Doing interprofessional research in the COVID-19 era: A discussion paper. Journal of Interprofessional Care, 34(5), 600-606. https://doi.org/10.1080/13561820.2020.1791808

Tagat, A., \& Kapoor, H. (2020). Go, corona, go! Cultural beliefs and social norms in India during COVID-19. Journal of Behavioral Economics for Policy, 4(Covid-19 Special Issue), 9-15.

Tarman, B. (2020). Editorial: Reflecting in the shade of pandemic. Research in Social Sciences and Technology, 5(2), i-iv. https://doi.org/10.46303/ressat.05.02.ed

Tosepu, R., Gunawan, J., Effendy, D. S., Ahmad, L. O. A. I., Lestari, H., Bahar, H., \& Asfian, P. (2020). Correlation between weather and Covid-19 pandemic in Jakarta, Indonesia. Science of the Total Environment, 725, Article 138436. https://doi.org/10.1016/j.scitotenv. 2020.138436

van den Boogert, J. (2017). The role of Slametan in the discourse on Javanese Islam. Indonesia and the Malay World, 45(133), 352-372. https://doi.org/10.1080/13639811.2017.1345166

Vetter, P., Kaiser, L., Schibler, M., Ciglenecki, I., \& Bausch, D. G. (2016). Sequelae of Ebola virus disease: The emergency within the emergency. The Lancet Infectious Diseases, 16(6), e82e91. https://doi.org/10.1016/S1473-3099(16)00077-3

Wang, S., Wang, Y., Lu, Y., Li, J., Song, Y., Nyamgerelt, M., \& Wang, X. (2020). Diagnosis and treatment of novel coronavirus pneumonia based on the theory of traditional Chinese medicine. Journal of Integrative Medicine, 18(4), 275-283. https://doi.org/10.1016/ j.joim.2020.04.001

Wiederhold, B. K. (2020). Turning to faith and technology during the coronavirus disease 2019 crisis. Cyberpsychology, Behavior, \& Social Networking, 23(8), 503-504. https://doi.org/10.1089/cyber.2020.29191.bkw

Wimalawansa, S. J. (2020). Global epidemic of coronavirus-Covid-19: What can we do to minimize risks. European Journal of Biomedical and Pharmaceutical Sciences, 7(3), 433438.

World Health Organisation. (2004). WHO guidelines on safety monitoring of herbal medicines in pharmacovigilance systems. World Health Organisation, Geneva. https://apps.who.int/iris/bitstream/handle/ 10665/43034/9241592214_eng.pdf;sequence=1

Yang, Y., Islam, M. S., Wang, J., Li, Y., \& Chen, X. (2020). Traditional Chinese medicine in the treatment of patients infected with 2019-New Coronavirus (SARS-CoV-2): A review and perspective. International Journal of Biological Sciences, 16(10), 1708-1717. https://doi.org/10.7150/ijbs.45538 
Zou, X., Tam, K. P., Morris, M. W., Lee, S.-1., Lau, I. Y. M., \& Chiu, C-y. (2009). Culture as common sense: Perceived consensus versus personal beliefs as mechanisms of cultural influence. Journal of Personality \& Social Psychology, 97(4), 579-597. https://doi.org/10.1037/a0016399

\section{Notes on Contributors}

Maila D.H. Rahiem is an Assistant Professor at the Faculty of Education, UIN Syarif Hidayatullah Jakarta. Her area of teaching and research focuses on the cultural and religious aspects of disaster preparedness and intervention, the well-being of children, the culture and value of education, and the use of stories and storytelling in early childhood education. Before becoming an educator, she worked as a humanitarian aid worker in conflict-affected and disaster-affected areas. Human stories have always fascinated her. This affects her research methods, which primarily use narratives as data sources.

Husni Rahim is Professor of Education at the School of Graduate Studies, UIN Syarif Hidayatullah Jakarta. Formerly Secretary of the National Higher Education Accreditation of the Republic of Indonesia (2003-2011) and Director General of Islamic Education at the Ministry of Religious Affairs of Indonesia (1998-2002). His fields of study include the Palembang Sultanate in the colonial era, the history of education, the administration of education and moral education. 